\title{
CORPORATE GOVERNANCE IN ROMANIA
}

\author{
Ciprian Apostol ${ }^{1}$
}

\begin{abstract}
The objective of the research was focused on measuring the performance level of corporate governance in Romania. This is carried out by evaluating the importance level given to the principles of corporate governance in the Romanian economy, while the practices of transparency and dissemination of companies' information in the selected sample were monitored. To achieve the objectives of the study, we need to examine the Corporate Governance Code of the Bucharest Stock Exchange. Sample companies were selected and their information from the "Comply or Explain" Statements was analyzed.

The research method is a non-participating observation-based on the information from the "Comply or Explain" Statement to determine whether companies are applying corporate governance and transparency elements. The research results highlight the progress of Romanian companies in the process of exercising to the principles of corporate governance, becoming internationally recognized, and integrating into the Corporate Governance Code of the Bucharest Stock Exchange.
\end{abstract}

JEL Classification Numbers: G34, M48, DOI: http://dx.doi.org/10.12955/cbup.v3.649

Keywords: Corporate Governance, "Comply or Explain" Statement, social performance, environmental performance

\section{Introduction}

The human society is faced with multiple and rapid changes in all fields. At economic and financial levels, the change highlights the gradual transition from the production of manufacturing type to the production of automated type, from individual knowledge to the group knowledge, which emphasizes the importance of communication. In this context, a "new economy" has emerged and developed, and "it is conducted with unprecedented speed and its effects will be more radical than anything happened before" (Drucker, 2001).

To achieve the microeconomic objectives of the "new economy," which aim to maximize the overall performance of the company, a good corporate governance is required. The debates about corporate governance have intensified since the 1990s, first in Anglo-Saxon countries, then in continental Europe, and then globally. Thus, after a series of financial scandals in the United Kingdom, in 1992, the Cadbury report was issued, which became the first corporate governance code and served as the foundation of corporate governance in European Union countries. During 1995-1999, France, Spain, Netherlands, Finland, Belgium, Italy, and Portugal developed their own codes of corporate governance, which had been inspired by this report. In 2000s, those Member States who had developed the first generation of codes of good practice began to adopt them. During 2000-2005, the other 17 Member States adopted corporate governance codes, four of which had already implemented the first generation of codes. Until 2007-2008, the last European Union countries adopted such codes (Luxembourg, Bulgaria, and Romania), so that, to date, all European Union Member States have at least one national code of corporate governance except for Ireland (applying "British Combined Code") and Greece (applying legal, mandatory rules in this respect) (Achim, 2013).

The first code of corporate governance in Romania was issued in June 2000 by the "International Center for Entrepreneurial Studies" and targeted public companies listed on Bucharest Stock Exchange (Berheci, 2013).

In 2001, the Organization for Economic Cooperation and Development (OECD), with the support of United States Agency for International Development (USAID), developed and published a program to improve corporate governance in Romania. In this regard, the Bucharest Stock Exchange, which had conducted the first trading only in 1995, created category Plus and adopted the first Corporate

\footnotetext{
${ }^{1}$ Ciprian Apostol, Faculty of Economics and Business Administration, "Alexandru Ioan Cuza" University, Iasi, Romania, ciprian.apostol@uaic.ro
} 
Governance Code for admission to stock exchange in 2001. This approach was to ensure that listed companies can improve in this category but only after adopting the stipulations of this Code.

In the following years, Bucharest Stock Exchange created Corporate Governance Institute, which has contributed to the adoption of the White Paper on Corporate Governance in South Eastern Europe countries.

In 2008, Bucharest Stock Exchange adopted a new Code of Corporate Governance. It is based on the OECD principles of corporate governance and has come into effect since the fiscal year 2009 by being applied voluntarily by exchange traded companies. The companies that have adopted all or part of this code must prepare the "Comply or Explain" Statement, specifying the recommendations, which have been implemented and how they were implemented (Bucharest Stock Exchange, 2008).

\section{Literature review}

As a topic of great interest, corporate governance has been discussed extensively in the literature and, therefore, has a variety of definitions.

In 1932, Adolf Berle and Gardiner Means developed the agency theory and established for the first time the term "good governance." In 1984, Tricker considered that the essential elements of good corporate governance are: company strategy, executive management, accountability, and supervision.

Shleifer \& Vishny (1997) defined corporate governance as the manner in which the stakeholders shall ensure that they will receive the benefits from their investment.

In Financial Times (1997), corporate governance is defined as a company's overall relations with its shareholders or, more broadly, society as a whole.

KonTraG (1998) has a strict accounting approach to corporate governance, which is defined as the regulation on the control and transparency of annual reports.

Kolk \& Pink (2009) concluded that corporate governance is highly related to corporate social responsibility.

According to International Finance Corporation (2015), "corporate governance refers to the structures and processes for the direction and control of companies. Corporate governance concerns the relationships among the management, Board of Directors, controlling shareholders, minority shareholders and other stakeholders."

Recently, Romanian authors are becoming more concerned about the concept of corporate governance. Thus, Ghiţă (2008) defined this concept as the management of the entire organization by accepting all internal components that function together, which, eventually, will integrate the management and the implementation of risk management together within the organization, as well as financial management and internal control system, including internal audit.

Morariu, Suciu, \& Stoian (2008) defined corporate governance as the system by which the companies are directed and controlled.

Bunget et al. (2009) asserted that although corporate governance is closely related to the management of an entity and its structures, it includes within its sphere important the issues related to social responsibility and ethical business practices.

\section{Research methodology}

The research purpose consists of measuring the level of social and environmental performance of the corporate governance system in Romania. 
The research method is a non-participating observation. It envisaged the reporting of "Comply or Explain" Statement by companies listed on Bucharest Stock Exchange to see whether the elements of corporate governance and transparency were applied.

Data source is the information on the website of the companies and posted on the website of the Bucharest Stock Exchange.

\section{Evaluation of corporate governance quality for listed companies on the Romanian market}

The quality of corporate governance will be monitored in two dimensions:

- Preparation and Reporting of "Comply or Explain" Statement

- Corporate social responsibility

Preparation and Reporting of "Comply or Explain" Statement is the first dimension of the quality of corporate governance. It will analyze whether the company prepares and reports this Statement. If so, this reflects the availability of compliance with good corporate governance practices contained in the Code of Bucharest Stock Exchange.

Corporate social responsibility is an attribute of corporate governance quality. This is supported by the recommendations of the Corporate Governance Code of the Bucharest Stock Exchange, which in Article 10 Social responsibility of issuer the Principle XVIII requires that "corporate governance structures should know and recognize the legal rights of any third interested parties - stakeholdersand encourage cooperation between the Issuer and these in order to create prosperity, jobs and view ensuring the sustainability of a strong company in financial terms."

In the "Comply or Explain" Statement, a single question is assigned: Does the Issuer carry on activities regarding the Issuer's social and environmental responsibility? The answer can be YES or NO, and if NO, EXPLAIN. Since the application of "Comply or Explain" Statement is most recent in Romania (starting with the annual reports for 2010) and 2014 companies have not generated their annual reports yet, the analysis period is from 2011 to 2013.

In the sample selection, companies that are traded on Bucharest Stock Exchange in Romania were taken into consideration on the assumption that they are more predisposed to apply the Corporate Governance Code and, therefore, the preparation and reporting of "Comply or Explain" Statement. To achieve this study, only the companies listed and traded in categories I, II, and III, were obtained; companies graded as "unlisted" were eliminated because they are not predisposed to respect the stipulations of Bucharest Stock Exchange and, therefore, do not complete the "Comply or Explain" Statement.

In the study, we obtained some information on reporting the corporate governance, social, and environmental performance, which is summarized in Table 1.

\begin{tabular}{|c|c|c|c|c|c|c|c|c|c|c|c|}
\hline \multicolumn{6}{|c|}{$\begin{array}{c}\text { Corporate governance performance. } \\
\text { Reporting of "Comply or Explain" Statement }\end{array}$} & \multicolumn{6}{|c|}{$\begin{array}{l}\text { Social and environmental performance. } \\
\text { Reporting of social responsibility activitie }\end{array}$} \\
\hline \multicolumn{2}{|c|}{2011} & \multicolumn{2}{|c|}{2012} & \multicolumn{2}{|c|}{2013} & \multicolumn{2}{|c|}{2011} & \multicolumn{2}{|c|}{2012} & \multicolumn{2}{|c|}{2013} \\
\hline YES & $\mathrm{NO}$ & YES & $\mathrm{NO}$ & YES & $\mathrm{NO}$ & YES & $\mathrm{NO}$ & YES & $\mathrm{NO}$ & YES & $\mathrm{NO}$ \\
\hline 57 & 22 & 66 & 9 & 72 & 6 & 60 & 19 & 68 & 7 & 72 & 6 \\
\hline \multicolumn{2}{|c|}{ TOTAL: 79} & \multicolumn{2}{|c|}{ TOTAL: 75} & \multicolumn{2}{|c|}{ TOTAL: 78} & \multicolumn{2}{|c|}{ TOTAL: 79} & \multicolumn{2}{|c|}{ TOTAL: 75} & \multicolumn{2}{|c|}{ TOTAL: 78} \\
\hline
\end{tabular}


Based on the data in Table 1, it can be seen that the number of companies in the sample selected in the three years of study is approximately equal (79 companies in 2011, 75 companies in 2012, and 78 companies in 2013).

The number of companies that prepared the "Comply or Explain" Statement increases from year to year. For instance, in 2011, only 57 of 79 companies (72.15\%) posted the Annual Report of the Trustees on their website in a separate section or as an integral part; in 2012, 66 of 75 companies (88\%) posted; and, in 2013, 72 of 78 companies (92.31\%) prepared such report. This is shown in Figure 1. The same trend is observed in the reporting of social and environmental performances. Thus, in 2011 only 60 of 79 companies (75.95\%) reported their social responsibility activities; in 2012, the number increased to 68 of 75 companies (90.67\%); and, in 2013, 72 of 78 companies $(92.31 \%$ ) reported this component. Reporting of social and environmental performance is presented in Figure 2 .

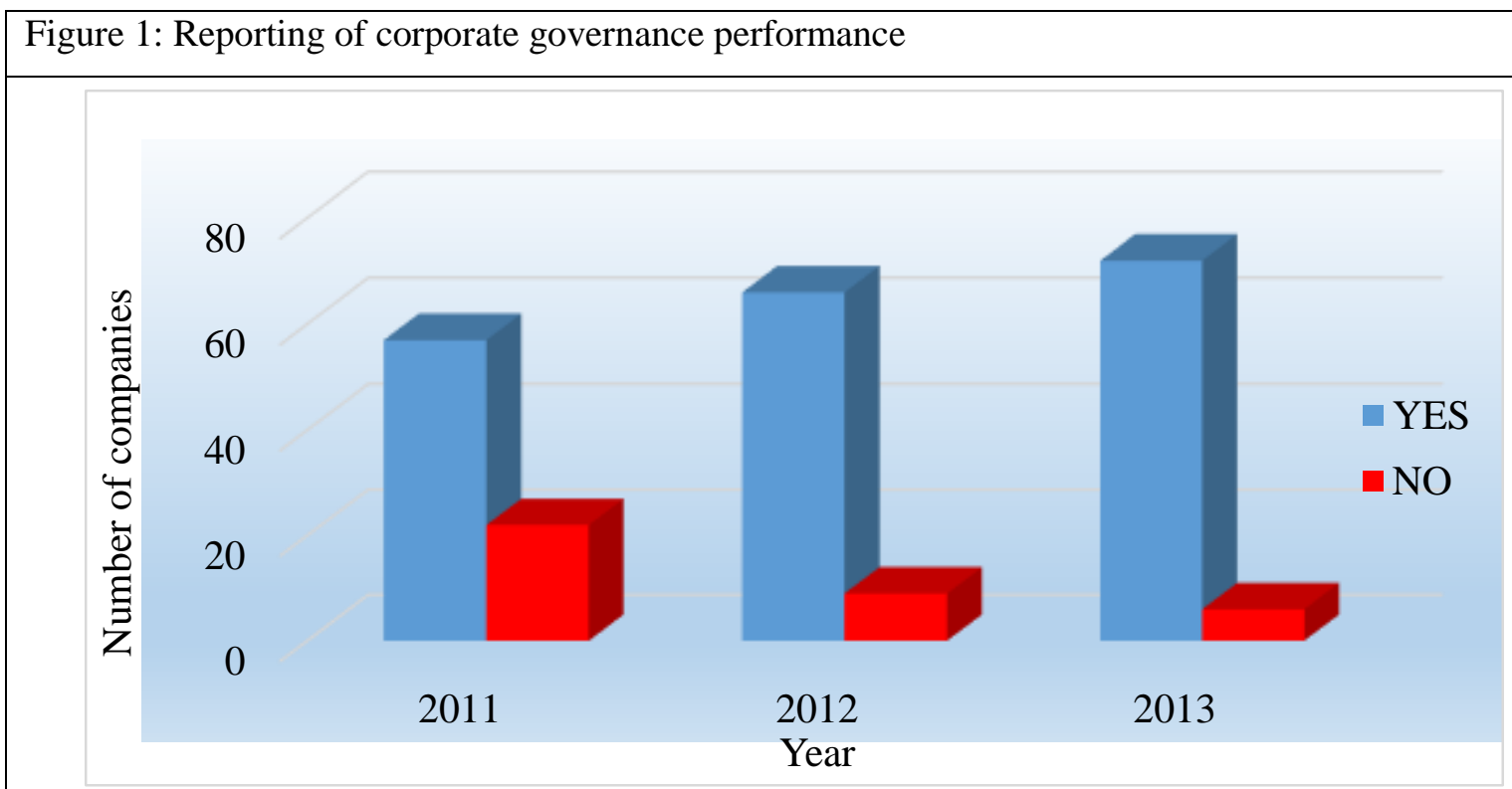

Source: Author

Figure 2: Reporting of social and environmental performance

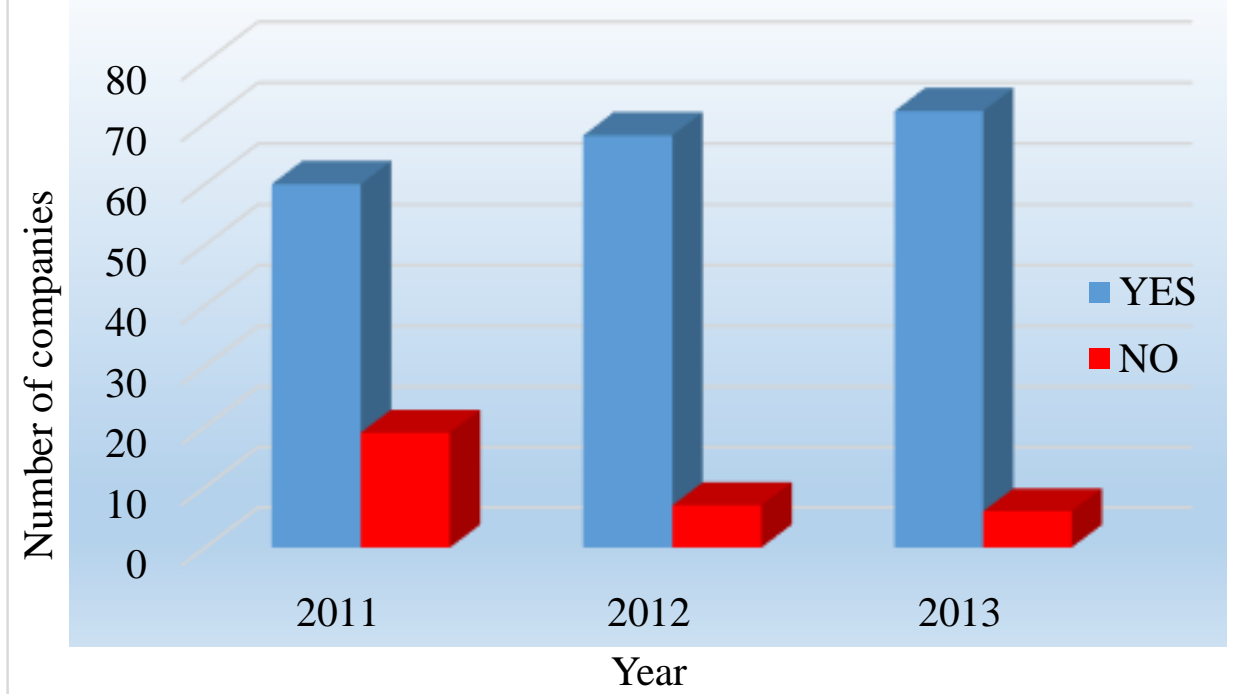

Source: Author 


\section{Conclusion}

In the conditions of capital market globalization, the companies are forced to adopt standards and procedures of corporate governance at a growing measure in order to become internationally recognized and to resist increasing competition for attracting funds.

In Romania, the implementation of corporate governance has a fairly recent history.

The study highlights the degree to which the companies listed on the Bucharest Stock Exchange adheres to internationally recognized principles of corporate governance and integrated in the Corporate Governance Code of the Bucharest Stock Exchange. The results reflect the increasing quality of corporate governance for listed companies on the Romanian market from 2011 to 2013.

Although there was an increase in the number of companies in Romania, which has adopted the good practices of corporate governance, implementation is, however, quite low compared to the European Union average or the average recorded for other emerging countries.

\section{Acknowledgment}

This work was co-financed by the European Social Fund through Sectorial Operational Programme Human Resources Development 2007-2013, project number POSDRU/159/1.5/S/142115 "Performance and excellence in doctoral and postdoctoral research in Romanian economics science domain."

\section{References}

Achim, M. V. (2013). Teoriile firmei și întreprinzătorul: reevaluări şi perspective [Theories of the firm and the entrepreneur: revaluations and insights]. Post-Doctorate Dissertation in Economics. Bucureşti: Editura Academiei Române.

Berheci, M. (2013). Responsabilitatea corporativă și performanțele companiilor multinaționale [Corporate responsibility and performance of multinational companies]. Post-Doctorate Dissertation in Economics. Bucureşti: Editura Academiei Române.

Bucharest Stock Exchange (2008). Retrieved from: http://www.bvb.ro/

Bunget, O. C., Florea-Ianc, Z., Ghiţă, M., Nicolau, C., Pereş, C. E., \& Pereş, I. (2009). Guvernanţa corporativă şi auditul intern [Corporate governance and internal audit]. Timişoara: Editura Mirton.

Drucker, P. (2001, November 1). The Next Society. The Economist.

Ghiţă, M. (2008). Guvernanţă corporativă [Corporate governance]. Bucureşti: Editura Economică.

International Finance Corporation (2015, March 20). Retrieved from http://www.ifc.org/wps/wcm/connect/Topics_Ext_ Content/IFC_External_Corporate_Site/Corporate+Governance

Kolk, A., \& Pinkse, J. (2009). The integration of corporate governance in corporate social responsibility disclosure. Retrieved from: http://ssrn.com/abstract=1350939

Morariu, A., Suciu, G., \& Stoian, F. (2008). Audit intern și guvernanță corporativă [Internal audit and corporate governance]. București: Editura Universitară.

Shleifer, A., \& Vishny, R. W. (1997). A Survey of Corporate Governance. The Journal of Finance, 52. 